\title{
Serine Proteinase Inhibitor Protein
}

National Cancer Institute

\section{Source}

National Cancer Institute. Serine Proteinase Inhibitor Protein. NCI Thesaurus. Code

C17122.

A protein that plays a role in the inhibition of serine proteinases. 